\title{
Importance of recreational shore angling in the archipelago of Madeira, Portugal (northeast Atlantic)
}

\author{
Roi Martínez-Escauriaza ${ }^{1,2}$, Margarida Hermida ${ }^{1,3}$, Sebastián Villasante ${ }^{4,5}$, Lídia Gouveia ${ }^{2}$, \\ Nuno Gouveia ${ }^{2}$, Pablo Pita ${ }^{4,5}$ \\ ${ }^{1}$ Oceanic Observatory of Madeira, Agência Regional para o Desenvolvimento da Investigação Tecnologia e Inovação. \\ Edifício Madeira Tecnopolo, Piso 0, Caminho da Penteada, 9020-105 Funchal, Madeira, Portugal. \\ (RM-E) (Corresponding author). E-mail: roimartinez@ hotmail.com. ORCID iD: https://orcid.org/0000-0003-1219-9937 \\ (MH) E-mail: margarida.hermida@mare-centre.pt. ORCID iD: https://orcid.org/ 0000-0002-0259-109X \\ ${ }^{2}$ Direção de Serviços de Investigação - DSI, Direção Regional das Pescas - DRP-RAM, Estrada da Pontinha, CP $9004-$ \\ 562, Funchal, Madeira, Portugal. \\ (LG) E-mail: lidia.gouveia@gov.madeira.pt. ORCID iD: https://orcid.org/ 0000-0001-6904-7673 \\ (NG) E-mail: nuno.gouveia@madeira.gov.pt. ORCID iD: https://orcid.org/0000-0003-4633-4674 \\ ${ }^{3}$ MARE - Marine and Environmental Sciences Centre, Agência Regional para o Desenvolvimento da Investigação, \\ Tecnologia e Inovação (ARDITI), Edifício Madeira Tecnopolo, Caminho da Penteada, 9020-105, Funchal, Madeira, Portugal. \\ ${ }^{4}$ Campus Do Mar, International Campus of Excellence, Spain. \\ (SV) E-mail: sebastian.villasante@ usc.es. ORCID iD: https://orcid.org/0000-0001-6296-4479 \\ (PP) E-mail: pablo.pita@usc.es. ORCID iD: https://orcid.org/0000-0001-9273-1481 \\ ${ }^{5}$ Faculty of Political and Social Sciences, Av. Angel Echevarry s/n, 15782 Santiago de Compostela, Spain.
}

\begin{abstract}
Summary: In 2017, a total of 4825 licences were issued for shore angling in Madeira. Surveys were conducted on 734 anglers, some in the government fisheries office during the licence request and others during the fishing activity. Shore angling is practised throughout the year, mostly at weekends and during day time, and with an increase in summer. More than $60 \%$ of the anglers are unemployed, have low incomes, and spend on average €254 per person per year on this activity, adding up to a total of $€ 1.16$ million per year. Shore angling average number of fishing days per year per fisher was $65.1 \pm 62.0$ and the average catch per unit of effort was $0.35 \pm 0.26 \mathrm{~kg} /$ angler/hour. The estimated total annual catch was $520.7 \mathrm{t}$. Forty-three teleost species, 2 elasmobranchs and 6 invertebrates were identified in the catches. Despite the limitations and inaccuracies inherent to the surveys, they still provided valuable information and gave a general perception of the recreational shore fisheries in Madeira. The possible impact on the most captured species, such as the white seabream, Diplodus sargus (Linnaeus, 1758), and the parrotfish Sparisoma cretense (Linnaeus, 1758), should be analysed because high fishing pressure could affect populations and ecosystems.
\end{abstract}

Keywords: recreational fishing; surveys; shore angling; anglers' perceptions; Madeira; Portugal.

Relevancia de la pesca recreativa desde la costa en el archipiélago de Madeira, Portugal (Atlántico nororiental)

Resumen: En 2017 se tramitaron un total de 4825 licencias para la pesca recreativa desde la costa en la Región Autónoma de Madeira. En este periodo se realizaron 734 encuestas a los pescadores de esta modalidad, algunas en las oficinas, durante el trámite necesario para obtener la licencia y otras a personas mientras estaban pescando. La pesca desde la costa es una actividad que se practica durante todo el año, principalmente los fines de semana y normalmente durante el día, con un aumento de pescadores durante el verano. Más del $60 \%$ están desempleados o tienen bajos ingresos, y gastan en promedio 254 $€$ por persona al año en esta actividad, contabilizándose un total de 1.16 millones de $€$ por año. El numero medio de días de pesca por pescador al año fue de $65.1 \pm 62.0$, mientras que la CPUE media fue de $0.35 \pm 0.26 \mathrm{~kg} / \mathrm{pescador} / \mathrm{hora}$. La captura anual total estimada fue de 520.7 t, y se identificaron 43 especies de teleósteos, 2 de elasmobranquios y 6 de invertebrados en las capturas. A pesar de las limitaciones e imprecisiones inherentes a las encuestas, por primera vez se ha logrado obtener una valiosa información, que nos permite tener una percepción general de la pesca recreativa desde la costa en Madeira. El posible impacto sobre las especies más capturadas, como el sargo Diplodus sargus (Linnaeus, 1758) y la vieja Sparisoma cretense (Linnaeus, 1758), debe ser analizado ya que están sujetos a una importante presión pesquera que podría afectar a sus poblaciones y al ecosistema.

Palabras clave: pesca recreativa; encuestas; pesca desde la costa; percepciones de los pescadores; Madeira; Portugal.

Citation/Como citar este artículo: Martínez-Escauriaza R., Hermida M., Villasante S., Gouveia L., Gouveia N., Pita P. 2020. Importance of recreational shore angling in the archipelago of Madeira, Portugal (northeast Atlantic). Sci. Mar. 84(4): 331-341. https://doi.org/10.3989/scimar.05046.30A

Editor: J. Lloret.

Received: February 24, 2020. Accepted: June 26, 2020. Published: September 15, 2020.

Copyright: $\odot 2020$ CSIC. This is an open-access article distributed under the terms of the Creative Commons Attribution 4.0 International (CC BY 4.0) License. 


\section{INTRODUCTION}

Recreational fishing is an activity with few social barriers practised in rural and urban areas by young and old people (Hickley and Tompkins 1998). It is one of the most ancient and popular leisure activities, involving roughly $10 \%$ of the population in developed countries (Arlinghaus and Cooke 2009, Arlinghaus et al. 2015, 2016). Recreational fisheries have been estimated to involve more than 100 million people in North America, Oceania and Europe (FAO 2016). In Europe an estimate of around nine million recreational fishers operate in coastal seas (Hyder et al. 2018).

Until recently, it was thought that catches of recreational fisheries were significantly lower than those of commercial fisheries, but recent studies have shown that in some areas catches are similar or even higher (Cooke and Cowx 2004, Zeller et al. 2008, Pita et al. 2018). Global fish catches have been estimated to be $14 \%$ higher if recreational fishing is added to commercial catches (Hyder et al. 2018).

Removing individuals from natural populations may have consequences for the ecosystem, and this subtraction could reach levels that threaten the survival of local species (Post et al. 2002, Coleman et al. 2004). Furthermore, recreational catches of juveniles and of key species could have severe impacts on ecosystems (Cooke and Cowx 2004) by reducing the stock size and average fish sizes (McPhee et al. 2002), which may even cause genetic and trophic changes and habitat degradation (Cooke and Cowx 2006, Lewin et al. 2006). Therefore, assessments and management of resources should take this component into account in order to effectively protect resources (Rangel and Erzini 2007, Cowx 2008, Smallwood et al. 2011). The integration of data of the most frequently captured species in recreational fishing and their abundance could provide more reliable catch estimates and could also improve stock assessments (Post et al. 2002, Cooke and Cowx 2004, Zeller et al. 2008).

To date, there are no studies available on the recreational marine fisheries in the archipelago of Madeira (Portugal), in the Northeast Atlantic. Until recently, the absence of legislation did not facilitate carrying out any investigation of the activity. There is therefore no information available on the number of sea anglers in the islands, their economic relevance or their ecological impacts on marine ecosystems. In this respect, this paper combines the information from licences and from a survey programme carried out in 2017, when the legislation was implemented. The main objectives of this study are (a) to characterize catches of marine recreational fishers, (b) to analyse the socioeconomic features of this recreational fishery, (c) to investigate anglers' perceptions about the current legislation and regulations that apply to this activity, (d) to evaluate the practice of subsistence fisheries, and (e) to establish comparisons of potential economic benefits between recreational and artisanal fisheries.

This study will provide a better understanding of the situation of marine recreational fisheries in Madeira, thus helping fishery managers and policy makers to achieve better resource management.

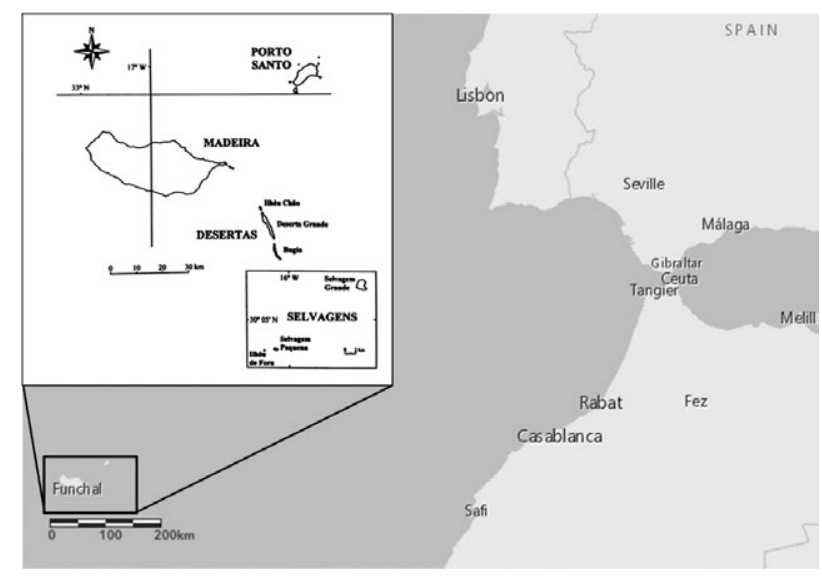

Fig. 1. - Map showing the Madeira Autonomous Region (RAM).

\section{MATERIALS AND METHODS}

\section{Area of study}

The archipelago of Madeira belongs to the region of Macaronesia (Fig. 1) and consists of two main inhabited islands, Madeira and Porto Santo, and five uninhabited islands (Desertas and Selvagens islands). The humid subtropical climate, with average temperatures ranging between $16^{\circ} \mathrm{C}$ in the winter and $22^{\circ} \mathrm{C}$ in the summer (Araújo et al. 2008), favours the practice of recreational fishing throughout the year.

The island of Madeira, the principal island of the archipelago, has a rough coastline with high cliffs and difficult access to the sea in many parts, especially on the north coast where the sea is rougher, explaining why $93 \%$ of people live near the southern coast (Quintal 2004, Direção Regional de Estatística da Madeira 2018). Porto Santo is a smaller island with a lower relief and a large sandy beach (Ribeiro and Ramalho 2009). Desertas and Selvagens islands are uninhabited and form marine protected areas (MPA, Quintal 2004). Recreational shore angling is not allowed in MPAs, so these islands have not been considered in this work.

\section{Licencing system and survey programme}

The new regional law regulating marine recreational fishing in 2016 (Regional Legislative Decree $\mathrm{N}^{\circ}$ 484/2016, 14 November 2016) includes the need for a recreational fishing licence that has to be requested at the Regional Fisheries Directorate of Madeira (DRP). In this study, information provided by anglers when obtaining their licences in 2017 was used to characterize this population, using features such as sex, age, socioeconomic status, licence type (annual or monthly), when it was obtained, and whether the anglers were exempt from payment (i.e. unemployed, retired or disabled).

Surveys were carried out throughout 2017 to collect information after a pilot study conducted on 69 anglers from November to December 2016. The pilot study permitted the validation of the initial questionnaires and included key topics relevant for anglers. Data obtained in the pilot study were also included in the analysis. A total of 653 surveys were carried out in 
2017; part of these (391) were conducted in the government office where anglers obtain their licences, and others were carried out when the anglers were practising shore angling at the usual access points (piers and beaches). The researcher collected basic demographic information on anglers (age, marital status, profession, etc.) and data related to the activity, including fishing frequency (number of trips per year), effort (number of hours per trip) and catches (estimated average weight of captured fish per trip). Moreover, information about the fishing methods used, the most frequently caught species and general opinions about fisheries management were collected (for more details, see the questionnaire in the Supplementary Material). When the surveys were performed during the fishing activity, permission to measure the catches was requested. Data from anglers without a licence were used to estimate their percentage of the total of anglers.

In 2018 only the number of licences per type (annual or monthly) was obtained, in order to assess the evolution of demand for licences in the following year.

\section{Data analysis}

To avoid the avidity bias, estimates of expenses, effort and catch per unit of effort (CPUE) were obtained on the basis of the surveys performed in the fisheries. To estimate the effort, the average duration of fishing trips was multiplied by the number of annual trips made by each angler. Anglers indicated the average catch weight per fishing trip, including trips with maximum catches and null catches. Dividing this value by the average duration of the trips, the CPUE value was obtained and expressed in weight $(\mathrm{kg})$ of fish caught per angler per hour.

To obtain more accurate results, the anglers were separated into groups based on the information of the licence database. In particular, the anglers were divided according to sex (male or female) and type of licence (annual or monthly). Estimated values of annual expenses, annual effort and CPUE were calculated at angler level and averaged for each group. To obtain the final average values per angler, firstly the mean annual expenses, annual effort and CPUE were multiplied by the number of licences of each group category; secondly, the values obtained for each group were added, thus giving the total annual expenses, annual effort and CPUE for the entire angler population. Finally, dividing each value by the total numbers of licences, we obtained the annual expenses, annual effort and CPUE per angler. The total recreational catch was calculated by multiplying the average CPUE by the average effort per angler. The value obtained was multiplied by the total number of anglers, who include people without licences (such as illegal anglers and underage anglers) and people with licences who do not fish. For this reason, a final correction including this portion of anglers was made. In particular, thanks to the surveys performed during the fishing activity, it was possible to calculate the percentage of anglers without a licence $(12.2 \%)$. Moreover, to estimate the number of people with licences who do not fish we used the result from
Table 1. - Recreational shore angling licences in Madeira grouped by island, sex and licence duration in 2017 (Regional Directorate of Fisheries).

\begin{tabular}{lcccc}
\hline & \multicolumn{2}{c}{ Porto Santo } & \multicolumn{2}{c}{ Madeira } \\
& Women & Men & Women & Men \\
\hline Annual & 31 & 390 & 418 & 3761 \\
Monthly & 2 & 57 & 20 & 146 \\
\hline
\end{tabular}

a previous study conducted in Spain (17\%; Ruiz et al. 2014) as a reference value, since no data were available for the region.

A one-sample Kolmogorov-Smirnov test was used to test data normality and a Levene test was used to assess variance homogeneity. One-way analysis of variance (ANOVA) was used to test for significant differences in expenses, fishing frequency and effort between the on-site survey (in the government office) and personal interviews (on fishing sites). A KruskalWallis test was used as a robust non-parametric alternative to ANOVA for the data that did not assume a normal distribution. All analyses were computed using PASW Statistics 22.0.

\section{RESULTS}

\section{Social characterization}

In 2017,4825 licences were issued for shore angling, of which 4600 were licences for the whole year and 225 for a single month (Table 1). In 2018 there was a notable decrease in the number of anglers who obtained annual licences (3805) but a slight increase in those who obtained monthly ones (237; Fig. 2).

In 2017 many anglers visited the Fisheries office to request the licence at the beginning of the year $(32 \%$ in January), so most questionnaires $(66.1 \%)$ were obtained from January until the end of March. In 2018 the licence requests were distributed throughout the year, with an increase in the summer months (Fig. 2).

The participation rate of people obtaining a recreational fishing licence was much higher in Porto Santo (9.3\% of the local population) than in Madeira (only $1.7 \%$ of the local population). For the entire region (254368 inhabitants) the participation rate was $1.9 \%$,



Fig. 2. - Evolution of the number of shore angling licences in 2017 and 2018. 
Table 2. - Recreational shore angling characteristics.

\begin{tabular}{|c|c|c|c|}
\hline \multicolumn{2}{|c|}{ Demographic characteristics } & \multirow{2}{*}{$\begin{array}{c}\% \\
92.2 \\
7.8\end{array}$} & \multirow{2}{*}{$\frac{n}{650}$} \\
\hline Sex & $\begin{array}{l}\text { Male } \\
\text { Female }\end{array}$ & & \\
\hline Residence & $\begin{array}{l}\text { Madeira } \\
\text { Funchal } \\
\text { Porto Santo }\end{array}$ & $\begin{array}{c}94.6 \\
58.9 \\
2.2\end{array}$ & 650 \\
\hline Education level & $\begin{array}{l}\text { No education } \\
\text { Basic } \\
\text { Secondary } \\
\text { Vocational training } \\
\text { University }\end{array}$ & $\begin{array}{c}2.2 \\
31.5 \\
44.5 \\
15.7 \\
6.1\end{array}$ & 635 \\
\hline Marital status & $\begin{array}{l}\text { Single } \\
\text { Married } \\
\text { Divorced } \\
\text { Widowed }\end{array}$ & $\begin{array}{c}36.3 \\
55.2 \\
6.7 \\
1.7\end{array}$ & 639 \\
\hline Employment & $\begin{array}{l}\text { Retired } \\
\text { Self-employed } \\
\text { Unemployed } \\
\text { Contract } \\
\text { Student } \\
\text { Pension (disability) } \\
\text { Civil servant }\end{array}$ & $\begin{array}{c}11.4 \\
9.9 \\
25.8 \\
40.2 \\
4.8 \\
1.1 \\
6.2\end{array}$ & 647 \\
\hline Monthly income & $\begin{array}{l}0 \\
0-500 € \\
500-1000 € \\
1000-1500 € \\
>1500 € \\
\text { Variable }\end{array}$ & $\begin{array}{c}37.7 \\
18.7 \\
25.9 \\
6.3 \\
1.9 \\
9.5\end{array}$ & 525 \\
\hline
\end{tabular}

and it is noteworthy that $9.8 \%$ of the licences were obtained by women.

In addition, in order to characterize the socioeconomic dimension of the recreational fisher population in the region, 734 anglers were interviewed. Eightyone anglers were unwilling to answer the questionnaire because of lack of interest. Of the 262 people surveyed during their fishing activity, 13 were underage and 19 did not have a licence. It is important to highlight that no licence is required for underage anglers. Therefore, the estimated percentage of anglers without a licence and underage people (12.2\%) allowed us to adjust the estimated number of anglers in the region to 5414 anglers. By subtracting the percentage of inactive anglers (17\%, Ruiz et al. 2014), it was estimated that the number of practising anglers in the Madeira archipelago was 4593.

The large majority of anglers (94.6\%) were Madeiran residents, more than half of whom lived in the capital, Funchal $(58.9 \%)$, while only $2.2 \%$ were from the island of Porto Santo (Table 2). The age group considered during the sampling process included individuals between the ages of 9 and 79 . Almost half of the individuals were aged between 31 and 50, with an average age of $42.9 \pm 14.9$.

The analysis of the marital status of the anglers indicated that $55.2 \%$ of the respondents $(n=639)$ were married, with an average age of $48.8 \pm 12.1$, and $36.3 \%$ were single, with an average age of $31.0 \pm 11.6$. There was also a small percentage $(6.7 \%)$ of divorced people, with an average age of $52.2 \pm 10.6$, and $1.7 \%$ widowed people, with an average age of $66 \pm 8.4$.

The average years of experience practising shore angling was $18.2 \pm 15.8$, ranging from people who had just started to veterans who had been fishing for 70 years. The older anglers usually had more experience, although some were newcomers who had started fishing as a retirement hobby. The average age at which anglers started fishing was $24.3 \pm 13.9$.

Regarding the education level, $33.7 \%$ of the interviewees $(n=635)$ had basic or no education, $44.7 \%$ secondary, $5.9 \%$ higher education and $15.7 \%$ had vocational training.

\section{Temporal and spatial patterns}

Some of the anglers $(34.7 \%), n=637)$ fished all around the island. Of the others, almost half (48.8\%) preferred fishing on the south coast, $15.5 \%$ on the north coast, $11.2 \%$ on the east coast, $7.4 \%$ on the west coast and $6 \%$ on the island of Porto Santo. Of the anglers, $38.6 \%$ went fishing where they lived, $10.8 \%$ close to their home and $40.9 \%$ close to the city. Moreover, $33 \%$ of the anglers $(n=645)$ were concentrated on the docks and platforms over the sea, $30.7 \%$ preferred rocky areas and only a low percentage preferred to fish at the beach $(6.5 \%)$. Most of the anglers $(63.9 \%)$ preferred to fish in company, only $13.7 \%$ said they usually fish alone and the others $(22.3 \%)$ had no preference $(n=633)$. The duration of the fishing activity was $5.3 \pm 2.3$ hours per fishing trip $(n=626)$. Almost $40 \%$ of those surveyed $(n=638)$ indicated no preference for the time of day to fish, $14.7 \%$ fished at night, $31.0 \%$ fished during the day (of which $15.7 \%$ in the morning, $5.2 \%$ in the afternoon) and $8.6 \%$ depending on the tides. A large percentage of the anglers $(82.3 \%)$ went fishing almost throughout the year $(n=638)$, but angling effort was greater at weekends.

\section{Fishing methods}

The most frequent methods used by recreational anglers were bottom fishing, surface fishing, hand line and spinning, and some anglers indicated that they also harvested invertebrates, including limpets, Patella spp. and/or sea snails, Phorcus sauciatus (Koch, 1845). Surface and bottom fishing were the most popular methods $(78.6 \%$ of the anglers, of whom $27.2 \%$ only practised surface fishing and $19.4 \%$ only bottom fishing). The other techniques were less frequent: $2.1 \%$ of the anglers used only spinning, $10.5 \%$ used spinning on some occasions combined with the other methods, $5.9 \%$ used hand lines occasionally, and $1.9 \%$ only used hand lines. Artificial baits were used by $17 \%$ of the anglers, mainly if they practised spinning or targeted squids. However, natural baits were more popular, including portions of small animals such as polychaetes, molluscs (mostly squid or snails), decapods or small fishes such as sardine Sardina pilchardus (Walbaum, 1792) and blue jack mackerel, Trachurus picturatus (Bowdich, 1825). Many anglers $(72.3 \%, \mathrm{n}=647)$ used previously caught bait (e.g. snails, crabs or small fishes) or bread $(77.9 \%)$.

\section{Catch composition, CPUE and effort}

Fifty-one species of fishes and invertebrates were recorded during the surveys, including 43 teleost spe- 
Table 3. - Species caught in Madeira waters. Lmat, length at maturity; Lleg, minimum landing size (numbers in bold are measures smaller than the minimum length at maturity); Min, minimum size; Max, maximum size (*, sizes smaller than those allowed by legislation; underlined, sizes smaller than the minimum length at maturity), all in $\mathrm{cm}$; $\mathrm{N}$, number of measured fishes; $€$, average first sale value (data provided by the Regional Directorate of Fisheries).

\begin{tabular}{|c|c|c|c|c|c|c|c|c|}
\hline Family & Scientific name & Lmat & Lleg & $\mathrm{N}$ & Min-Max & Average & $\begin{array}{l}\text { Recreational } \\
\text { estimated \% }\end{array}$ & $€$ \\
\hline \multicolumn{9}{|l|}{ OSTEICHTHYES } \\
\hline Balistidae & Balistes capriscus & 16.3 & & 10 & $33-38$ & 35.4 & 1.50 & 2.7 \\
\hline Belonidae & Belone belone & 28.5 & & & & & 0.15 & \\
\hline Bothidae & Bothus podas & 14.1 & \multirow[t]{3}{*}{24} & & & & 0.03 & \\
\hline Carangidae & Pseudocaranx dentex & 27.8 & & 1 & $\underline{13}$ & 13 & 0.79 & 8 \\
\hline Carangidae & Seriola rivoliana & 81.1 & & & & & 0.76 & 3.7 \\
\hline Carangidae & Trachinotus ovatus & 39.1 & \multirow[b]{2}{*}{15} & 13 & $12-31$ & 16.6 & 4.32 & 1.4 \\
\hline Carangidae & Trachurus picturatus & 24.7 & & & & & 0.53 & 1.1 \\
\hline Clupeidae & Sardina pilchardus & 14.8 & \multirow[t]{2}{*}{11} & & & & 0.13 & 0.7 \\
\hline Clupeidae & Sardinella maderensis & 13.4 & & & & & 0.01 & 0.4 \\
\hline Congridae & Conger conger & 200 & \multirow[t]{2}{*}{58} & \multirow{3}{*}{28} & \multirow{3}{*}{$12-21$} & \multirow{3}{*}{15.3} & 0.06 & 1.7 \\
\hline Haemulidae & Pomadasys incisus & & & & & & 1.41 & 3.5 \\
\hline Kyphosidae & Kyphosus sectator & 48.8 & & & & & 0.53 & \multirow[t]{4}{*}{2.6} \\
\hline Labridae & Centrolabrus trutta & & & \multirow{2}{*}{3} & \multirow[t]{2}{*}{$13-18$} & \multirow[t]{2}{*}{15.3} & 0.04 & \\
\hline Labridae & Coris julis & 8.7 & & & & & 0.04 & \\
\hline Labridae & Thalassoma pavo & 15.7 & & 14 & $\underline{12-16}$ & 13.7 & 1.72 & \\
\hline Mugilidae & Chelon spp. & 29.5 & 20 & \multirow[t]{4}{*}{21} & \multirow[t]{4}{*}{$\underline{12-52^{*}}$} & \multirow[t]{3}{*}{25} & 6.89 & 2.1 \\
\hline Mullidae & Mullus surmuletus & 16.1 & 15 & & & & 0.26 & 11 \\
\hline Muraenidae & Muraena spp. & & & & & & 0.37 & 1.6 \\
\hline Phycidae & Phycis phycis & 35.6 & 37 & & & & 0.21 & 2.9 \\
\hline Pomacentridae & Abudefduf luridus & 10 & & \multirow[t]{2}{*}{12} & $10-13$ & 11.6 & 2.80 & 5.6 \\
\hline Pomacentridae & Chromis limbata & 8.2 & & & & & 0.08 & 9.9 \\
\hline Pomatomidae & Pomatomus saltatrix & 30 & & 1 & $\underline{20}$ & 20 & 2.07 & 2.7 \\
\hline Scombridae & Scomber colias & 21.5 & 20 & & & & 0.99 & 1.1 \\
\hline Scorpaenidae & Scorpaena maderensis & $8.7-9.9$ & & & & & 0.02 & \\
\hline Serranidae & Mycteroperca fusca & & & & & & 0.03 & 7.9 \\
\hline Serranidae & Serranus atricauda & 25 & & 2 & $17-23$ & 20 & 1.61 & 5.2 \\
\hline Sparidae & Boops boops & 14.3 & 15 & 18 & $11-18^{*}$ & 13.7 & 6.32 & 1 \\
\hline Sparidae & Dentex gibbosus & 34.7 & & 2 & $21-24$ & 22.5 & 0.23 & 7.3 \\
\hline Sparidae & Diplodus cervinus & & & & & & 0.38 & 7.8 \\
\hline Sparidae & Diplodus sargus & 16.7 & 15 & 9 & $14-36^{*}$ & 22 & 15.73 & 5.2 \\
\hline Sparidae & Diplodus vulgaris & 17 & 15 & 6 & $\underline{12-27} *$ & 19.5 & 2.44 & 3.9 \\
\hline Sparidae & Lithognathus mormyrus & 18.8 & 15 & 1 & 35 & 35 & 0.52 & 3 \\
\hline Sparidae & Oblada melanura & & & 6 & $12-23$ & 16.6 & 6.62 & 2.4 \\
\hline Sparidae & Pagellus acarne & 16 & 18 & 23 & $12-24^{*}$ & 26.3 & 2.38 & 4.7 \\
\hline Sparidae & Pagellus bogaraveo & 31.4 & 25 & & & & 0.05 & 7.1 \\
\hline Sparidae & Pagellus erythrinus & 14.7 & 15 & 8 & $17-25$ & 19.8 & 2.99 & 5 \\
\hline Sparidae & Pagrus pagrus & 26.6 & 20 & 3 & $11-28^{*}$ & 20.3 & 7.76 & 6.6 \\
\hline Sparidae & Sarpa salpa & 16.5 & 18 & 17 & $14-29 *$ & 22.2 & 7.34 & 3.8 \\
\hline Sparidae & Sparisoma cretense & 15.5 & & 8 & $\overline{17-27}$ & 22.1 & 10.75 & 7.2 \\
\hline Sparidae & Sparus aurata & & & 8 & $12-16$ & 13.5 & 1.63 & 4.4 \\
\hline Sphyraenidae & Sphyraena spp. & $59.5-62.5$ & & 3 & $65-81$ & 72.6 & 2.47 & 2.9 \\
\hline Synodontidae & Synodus saurus & & & 1 & 15 & 15 & 0.06 & \\
\hline Tetraodontidae & $\begin{array}{l}\text { Sphoeroides spengleri / } \\
\text { Canthigaster rostrata }\end{array}$ & & & 6 & $11-15$ & 12.6 & 0.24 & \\
\hline CHONDRICTHYES & & & & & & & & \\
\hline Rajiformes & Raja spp. & & & & & & 0.48 & 0.8 \\
\hline Triakidae & Mustelus spp. & & & & & & 0.32 & 1.6 \\
\hline INVERTEBRATES & & & & & & & & \\
\hline Arthropoda: Decapoda & & & & & & & & \\
\hline Grapsidae & Grapsus webbi & & & & & & 0.04 & \\
\hline Mollusca: Cephalopoda & & & & & & & & \\
\hline Loliginidae & Loligo vulgaris & & & & & & 0.47 & 7.3 \\
\hline Octopodidae & Octopus vulgaris & & & & & & 0.24 & 8.7 \\
\hline Sepiidae & Sepia officinallis & & & & & & 0.17 & 1.6 \\
\hline Mollusca: Gastropoda & & & & & & & & \\
\hline Patellidae & Patella spp. & & & & & & 2.91 & 3.6 \\
\hline Trochidae & Phorcus sauciatus & & & & & & 0.10 & 6.1 \\
\hline
\end{tabular}

cies, 2 elasmobranchs and 6 invertebrates (Table 3). The families Sparidae and Carangidae were the most frequent in the catches, with 13 and 4 species, respectively. The most frequent species in the catches were white seabream and parrotfish.

Regarding the 224 measured fishes of 25 different species, the most frequent species were bastard grunt (Pomadasys incisus [Bowdich, 1825]), axillary seabream (Pagellus acarne [Risso, 1827]), and mullets (mostly Chelon spp.), with 28, 23 and 21 individuals, respectively. Of the measured fishes, $18.2 \%$ belonging to seven species were below the minimum landing size (Table 3).

Some shore anglers completed their catches with the collection of invertebrates, composed mainly of the limpets Patella candei d'Orbigny, 1839 and P. aspera Röding, 1798 and the sea snail Phorcus sauciatus, all collected in the intertidal zone. Also, some cephalopods such as Octopus vulgaris Cuvier, 1797, the longfinned squid, Loligo vulgaris Lamarck, 1798, and the 
Table 4. - Madeiran anglers CPUE (kg/angler/hour) and effort (in hours) stratified by sex and licence duration.

\begin{tabular}{lcc}
\hline & CPUE & Men \\
\hline Annual & $0.24 \pm 0.16(\mathrm{n}=17)$ & $0.42 \pm 0.31(\mathrm{n}=339)$ \\
Monthly & $0.18 \pm 0.03(\mathrm{n}=3)$ & $0.28 \pm 0.31(\mathrm{n}=10)$ \\
\hline \multicolumn{3}{c}{ Effort } \\
Women & Men \\
\hline Annual & $313.59 \pm 359.66(\mathrm{n}=17)$ & $368.9 \pm 486.2(\mathrm{n}=354)$ \\
Monthly & $34.670 \pm 26.08(\mathrm{n}=3)$ & $77.65 \pm 109.51(\mathrm{n}=10)$ \\
\hline
\end{tabular}

Table 5. - Estimated mean expenses of anglers (in €) by sex and type of licence (annual or monthly).

\begin{tabular}{lcc}
\hline & Women & Men \\
\hline Annual & $76.67 \pm 32.52(\mathrm{n}=12)$ & $316.2 \pm 580.37(\mathrm{n}=313)$ \\
Monthly & $30.0 \pm 23.1(\mathrm{n}=4)$ & $42.9 \pm 29.3(\mathrm{n}=9)$ \\
\hline
\end{tabular}

common cuttlefish, Sepia officinalis Linnaeus, 1758, were fished (Table 3).

Almost all fishers $(96.4 \%)$ used the catches for consumption. About half of them (49.4\%) released only small fish and fish without gastronomic value, $3.2 \%$ claimed to always practise catch-and-release, and $17.1 \%$ usually gave away part of the catch. A small group of anglers (3.5\%) admitted to selling their catches illegally.

Expenses, average number of hours per fishing trip and CPUE were homogeneous between surveys conducted in the government office and at the fishing sites (ANOVA and K-W test, $\mathrm{p}>0.05$ ), whereas the fishing frequency was significantly different between the two groups $(\mathrm{K}-\mathrm{W}$ test, $\mathrm{p}<0.01)$. The data showed that anglers interviewed at fishing sites spent on average 83.2 $\pm 71.2(n=261)$ days fishing, while anglers surveyed in the government office spent only $65.1 \pm 62$ $(n=381)$ days fishing.

To reduce the avidity bias as much as possible, only the surveys performed in the offices were used to obtain the following results.

After the stratification of angler groups by sex and type of licence to correct the estimates (Table 4), the average CPUE was $0.35 \pm 0.26 \mathrm{~kg} /$ angler/hour $(\mathrm{n}=369)$. Considering the total of 4825 licences for shore angling, and after a correction for anglers without licence
(7.3\%), underage (5\%) and inactive anglers (17\%), the estimated annual catch was 520.7 t per year, i.e. an average of $113.3 \mathrm{~kg}$ per person per year. The average number of fishing days per year per fisher was $65.1 \pm 62.0$, the average of hours per day per fisher was $5.2 \pm 2.0$ and the total effort was $1,457,077.7$ fishing hours per year, corresponding to $317.2 \pm 413.5$ hours per fisher per year $(n=384)$.

\section{Economic characterization}

Some anglers $(19.7 \%)$ refused to provide information about their salary. A few (10\%) were self-employed and $7.6 \%$ declared that their salary was highly variable. Almost half of the anglers (40\%) admitted to having no income or relying on social benefits (of these, $30.6 \%$ were unemployed, $11.4 \%$ were retired and $1.1 \%$ were disabled). In terms of income, $20.7 \%$ of the anglers earned less than $€ 500$ per month and only $2.1 \%$ had a salary above $€ 1500$ per month. Unemployed, retired or disabled anglers $(15.2 \%)$ were exempt from licence payment.

The mean annual expenditure after correction by sex and type of licence was €254.3 \pm 413.5 per angler (Table 5). After a subsequent correction of unlicensed and underage people, total expenditure was estimated to be $€ 1.16 \mathrm{M}$.

\section{Perceptions of recreational fishers}

Of the anglers, $13.8 \%$ recognized the need for licences, while $10.6 \%$ considered that they were unnecessary. A few of them $(7.7 \%)$ recognized some advantages of the new fishing licence legislation, $2.1 \%$ commented that the licences should be cheaper and $18.2 \%$ said that they should be free. Some anglers who did not see any advantages of the new legislation believed the ocean belongs to everyone and should therefore not be regulated. Moreover, they considered the licences as a form of taxation, because they were not reflected in improvements for them or for the fishery. In addition, $17.2 \%$ of the anglers thought that the fish size control by the authorities was weak and $6.8 \%$ suggested that anglers should be part of the implemen-

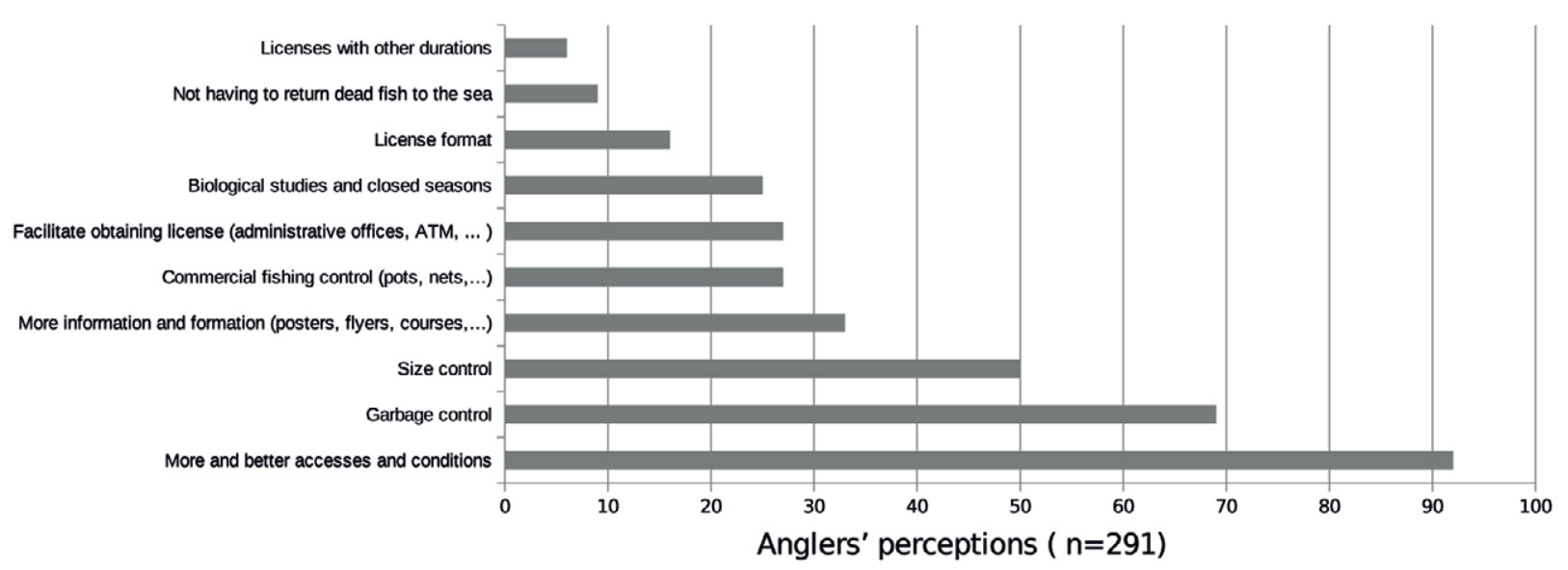

Fig. 3. - Anglers' perceptions about recreational fisheries regulation and possible improvements. 
tation of new legislations (Fig. 3). A small number of anglers $(8.6 \%)$ considered it necessary to invest in the improvement of fish stock health, considering it important to increase the knowledge of target species and the state of ecosystems and to involve and encourage anglers to help in research programmes. Some of the anglers $(11.3 \%$ ) highlighted the importance of information being available at the main access points to fishing activity, such as fishing equipment stores and licencing offices, to improve their knowledge regarding sustainable fishing practices and security. A high number of anglers $(69.5 \%)$ reported a decline in catches along the coast. Most of them (57.4\%) related the decline to the debris generated from construction of new coastal infrastructure that created a layer of mud on the bottom impacting the habitats. Other problems reported during the surveys included the catch of a large proportion of fish below the minimum landing size $(17.1 \%)$ and the waste generated during fishing $(23.7 \%)$.

Some anglers (5.5\%) suggested that the licence would be better in the form of a card instead of a paper sheet. Finally, 2.1\% suggested that licences with different durations, such as weeks, years or even lifelong licences, should be available.

\section{DISCUSSION}

\section{Social characterization of anglers}

Thanks to the new regional regulation on marine recreational fishing in 2016 (Regional Legislative Decree $\mathrm{N}^{\circ}$ 484/2016, 14 November 2016), which includes the need for a licence to conduct fishing activities, it was possible for the first time to quantify the number of recreational fishers in the region of Madeira.

In summer, the number of licence requests increased, mainly the monthly ones, probably due to the large number of people on holidays with more leisure time to practise the activity. However, many anglers without licence were tourists (40\%), probably due to lack of knowledge of the recently implemented law. This amount of illegal fishing might be avoided through the display of information signs in the most common fishing areas, as suggested by some anglers during the surveys $(11.3 \%)$.

The decrease of $17.2 \%$ in the number of annual licences between 2017 and 2018 could be because the new law with the fishing licence requirement was regulated in 2017 and most anglers decided to request it considering that they were going to fish regularly all year long (a large number of licences were requested in the first month of the year). In 2018 some anglers might have delayed requesting the licence to a more favourable season, as its validity is for one year from the date of request, or might have preferred the monthly licence for economic reasons. This observed decrease from one year to the next can serve as confirmation of the high percentage of people who do not fish despite having obtained a licence. The result obtained is very close to that obtained for Spain (Ruiz et al. 2014), which was used as a correction for the final estimates.
Unemployed, retired and disabled anglers were exempt from licence payment $(15.2 \%)$, but $34.5 \%$ of anglers belonging to these categories still paid for the licence because the only office where it was possible to obtain the free licence was located in another city (Câmara de Lobos). This problem has since been rectified, with the introduction of online and ATM payments.

New regulations are usually based on previous studies from other regions, which could have different environmental characteristics and a different state of the local populations of the target species. Therefore, some inaccuracies in the new fishing legislation of Madeira were found, such as the daily bag limits established for the stock control and designed to reduce fishing mortality of highly exploited species, because no studies in Madeira were performed to correctly allocate sustainable fishing quotas to each species (Attwood and Bennett 1995). Moreover, the minimum landing sizes of many species of interest are smaller than the length at maturity (Table 3; Froese and Pauly 2019), thus compromising the reproduction of these species (Pita et al. 2016).

The participation rate in shore angling in the Autonomous Region of Madeira (1.9\%) is similar to the average for mainland Portugal $(1.7 \%)$ and the European Atlantic region (1.7\%; Hyder et al. 2018) but lower than that in the neighbouring Canary Islands (3.1\%; Gordoa et al. 2019). The participation rate in Porto Santo is quite high $(9.2 \%)$ compared with other countries; in fact it was only surpassed by Norway $(33.0 \%)$ and Iceland (31.5\%) in Europe, and by Oceania (17\%-19.5\%) worldwide (Cisneros-Montemayor and Sumaila 2010, Hyder et al. 2018). The high participation rate in Porto Santo is probably explained by the characteristics of the island, such as its dry environment, its limited resources and its low productivity, rendering fishing a valuable resource. Hermida and Costa (2020) also observed greater involvement in subsistence fishing in Porto Santo Island.

Despite the proximity between Porto Santo and the main island of Madeira, their environment is very different. Madeira is characterized by irregular and abrupt coasts, and the access to the sea is difficult in many places. For this reason, the docks are usually the areas most frequently used for fishing, but some of them cannot be used to practise the activity because of their proximity to ports and/or bathing areas. Moreover, areas with access to the sea are mainly occupied by large resorts, nautical clubs and hotels. For this reason, the conditions and accesses to fishing along the coast should be improved, in particular in Funchal, where an important percentage of anglers (21.5\%) were concentrated.

Compared with other locations, a considerable percentage of anglers in Madeira were women (9.7\%). In fact, the percentage of women anglers in Algarve and in Galicia was $1 \%$ (Veiga 2012, Veiga et al. 2010, Pita et al. 2017a), in Pico and Faial Islands, Azores 6.8\% (Diogo and Pereira 2014) and in Tenerife, Canary Islands 7\% (Pascual-Fernández et al. 2012). Higher numbers of women anglers were registered in Cap de Creus, Catalonia, reaching $12 \%$ of the total (Font and 
Lloret 2011). More than half of the anglers (55.2\%) were married, a little higher than the percentage of Madeiran citizens (42.3\%; Direção Regional de Estatística da Madeira 2018), but lower than the value recorded in Galicia (68\%) by Pita et al. (2018).

\section{Temporal and spatial patterns}

In relation to the favourite places to go fishing, one third of the anglers fished all around the island, changing spots, probably following the best weather around the island. Almost half the anglers preferred fishing on the south coast, while some preferred the north coast, considering that the environment there is less polluted and fishes more abundant because the area is less inhabited. Nevertheless, most preferred fishing around metropolitan areas because the fishing points are more accessible. Moreover, most of the anglers preferred fishing on the docks and platforms over the sea, or in rocky areas, and only a low percentage preferred to fish at the beach, probably because of the discomfort of the natural pebble beaches of Madeira. In addition, most beaches are bathing areas where fishing is restricted, and most of the target species live in rocky areas.

The presence of anglers was abundant throughout the year, but issued licences show a slight rise in summer months, similarly to what is observed in northern Portugal (Rangel and Erzini 2007), because people are on holiday then and have more free time. Nevertheless, the presence of anglers throughout the year suggests that fishing also takes place during the winter months, possibly because of the year-round mild weather conditions in Madeira. This keeps pressure on fishing resources throughout the whole year.

\section{Catch composition, CPUE and effort}

Catch and effort values obtained were quite high (0.35 kg/angler/h) when compared with mainland Portugal: $0.21 \mathrm{~kg} / \mathrm{angler} / \mathrm{h}$ in southern Portugal (Veiga et al. 2010), and $0.07 \mathrm{~kg} /$ angler/h in northern Portugal (Rangel and Erzini 2007). In Cap de Creus (Spain), the CPUE ranged between 0 and $0.10 \mathrm{~kg} /$ angler/h with a mean value of $96 \mathrm{~g}$ per angler per hour (Font and Lloret 2011). CPUE in Madeira was higher than in Tenerife, Canary Islands $(0.10 \mathrm{~kg} / \mathrm{angler} / \mathrm{h}$; Pascual-Fernández et al. 2012), but lower than in Pico and Faial islands, Azores, (0.83 kg/angler/h; Diogo and Pereira 2014).

Results obtained from surveys can show a degree of imprecision of the catches, influenced by the constraints associated with in situ survey methods (Lockwood 2000). Despite this, the results of the present study seem to confirm that the anglers interviewed in the fishing areas fish more frequently anglers than the anglers interviewed during the licence request. This can create an avidity bias that normally leads to an overestimation of the results. Hence, anglers interviewed at the fishing sites were excluded from the analysis, which, in addition to the stratification of the samples and the corrections applied, renders the results more accurate.
Many anglers complement their catch with the manual collection of invertebrates, mainly limpets. Limpets have been highly exploited for human consumption, constituting a permanently available resource which can be collected daily from the beginning of April to the end of November, up to a maximum of $3 \mathrm{~kg}$ per angler per day (Regional Legislative Decree $\mathrm{N}^{\circ}$ 40/2016). A previous study in the Azores estimates that the undeclared catch of limpets in the Azores is 60 times greater than the amount reported in the official statistics each year (Pham et al. 2013).

Analysing the catches made by anglers, it was observed that undersize fish are often captured (31.1\%), and at least seven targeted species were all lower than the minimum landing size (Table 3). Moreover, the legal minimum landing sizes of some of the targeted species are lower than the real maturity sizes (Froese and Pauly 2019; Table 3). It would be advisable to revise the sizes in the Regional Legislative Decree $\mathrm{N}^{\circ}$ $484 / 2016$

The most commonly caught species in Madeira coincided with those of nearby regions: $D$. sargus is one of the most caught species in southern Portugal (Veiga et al. 2010) and D. sargus and S. cretense are the most fished species in the Azores (Diogo and Pereira 2014) and Tenerife (Pascual-Fernández et al. 2012).

It is important to highlight the presence in the catches of the non-indigenous species Sparus aurata Linnaeus, 1758 , which was the sixteenth most frequently caught fish species. Sparus aurata was introduced to the Madeira islands in 1997 (Alves and Alves 2002, Wirtz et al. 2008) due to escapees from marine cage aquaculture resulting from equipment malfunction, accidents, predator activity, storms, etc. (Alves and Alves 2002). Farmed gilthead seabream escapees might have direct impacts on the environment (Toledo-Guedes et al. 2014, Arechavala-Lopez et al. 2018), as they can compete with native species of similar ecological and feeding habitats for the exploitation of natural resources (Balart et al. 2009).

Another unexpected species reported in the catches was Mustelus spp., despite its capture and retention being prohibited, with regulations stating that, if accidentally caught, it should be immediately released.

\section{Economic characterization}

The data obtained from the economic characterization of the population that practises fishing showed a large percentage of anglers with low or no reported income. The percentage of anglers without income was higher $(30.6 \%)$ than the percentage of Madeiran unemployed citizens (10.4\%; Direção Regional de Estatística da Madeira 2018). These results suggest that most of the anglers practised this activity as a regular food source and/or to obtain extra income. Selling all or part of the catch is common among recreational fishers in several countries, including Portugal (Lloret et al. 2016, Pita et al. 2017a,b). This practice is more common in anglers with low income or among retired professional fishers who continue their activities with a recreational licence (Lloret et al. 2016, Pita et al. 
$2017 b$ ). In the present study, only $3.5 \%$ of anglers confirmed that they generally sell their catches, but the percentage is probably underestimated, since it is an illegal practice. To avoid or reduce this practice, Pita et al. (2017b) propose that retired professional fishers be afforded an economic complement to the lowest pensions.

Anglers spent around €254 per year on fishing activity. This amount is low if compared with expenses in mainland Portugal (€796) or Spain (€729), (Hyder et al. 2018), but it is similar to that reported by Veiga et al. (2013) for southern Portugal, where annual expenditure on fishing equipment was around $€ 266$.

\section{Perceptions analysis of recreational fisheries}

Though many anglers accepted the new legislation, their opinions differed regarding the need for a licence. The surveys were performed in 2017, the first year in which the legislation requiring licences came into effect in Madeira. In other regions, such as the southern Portugal, recreational fishing licences have been mandatory for several years, and anglers generally accept the need for regulation of this type of fishery (Veiga et al. 2013). Some anglers commented that the licence should be cheaper or even free, as do Spanish anglers, some of whom suggest changes to the licence system, including the price (Pita et al. 2017a).

Moreover, some anglers considered the information about fishing legislation and condition to be insufficient, as is the case in other Portuguese regions, where anglers have complained about the lack of information (Rangel and Erzini 2007, Veiga et al. 2010). In Madeira, only a third of the surveyed anglers were familiar with the new laws; others were unaware of even basic information such as species size limits and restricted fishery areas, which suggests the need for a stronger effort by authorities in providing this information. Fishery rules can be consulted on the internet, but for many of the anglers this is complicated because of their advanced age and/or low levels of education. An angler training programme should be implemented and more information should be placed in the fishing areas.

In the last few years, a large number of anglers have observed a significant decrease in fish abundance in Madeiran coasts. The same trend was declared by anglers in southern Portugal (Veiga et al. 2013) and Spain (Cardona and Morales-Nin 2013). Anglers suggested that one of the main causes is the debris generated by works carried out over the last few years, a problem already described in Madeira (Hermida and Delgado 2016). Coastal environmental degradation is caused by sand mining, dredging and aggregate extraction and grinding for the construction industry, contributing to the further collapse of the coastal environment (Lopo 2004, Hermida and Delgado 2016). This can result in destruction of appropriate nursery and recruitment habitats for coastal fishes and the limitation of primary production by increased turbidity, decreasing fish recruitment and increasing fish mortality. Pollution and overfishing are other important reasons that anglers have pointed out as possible causes of the decline in fish abundance, as reported by Veiga et al. (2013). Most of the coastal areas of the world have been reported to be damaged by pollution and overfishing, significantly affecting the coastal environment (Pauly et al. 2003, Watson et al. 2003, Villasante 2009). It is interesting to note that many anglers consider that inspections are too infrequent, as has already been pointed out in other studies (Brouwer et al. 1997, Cardona and MoralesNin 2013).

\section{Survey bias}

Collecting data and obtaining accurate information on shore recreational fishing is difficult due to the large number of anglers involved, leading to small and possibly unrepresentative samples (NRC 2006). Identifying potential biases and classifying them may be useful in order to better interpret the data from surveys (Groves et al. 2004). Errors of representation are generated when samples do not represent the population accurately (Groves et al. 2004), and in fisheries surveys these errors usually include the coverage error and the non-response error (NRC 2006). A coverage error may be caused by interviewing anglers during the fishing activity, since there is a higher probability of interviewing avid anglers than those who do not practise fishing frequently. People with little experience or without catches are often less likely to answer (Zarauz et al. 2015), so results are usually biased towards an over-representation of anglers with more experience and higher catches (the avidity bias). For this reason, part of the analysis was performed only with data obtained in the fisheries office when anglers were applying for the licence. Moreover, it is common for anglers to refuse to take part in surveys or not to answer some questions, leading to unrepresentative results (Fisher 1996). In this study, $11.0 \%$ of interviewees refused to participate in the survey, and $35.5 \%$ of the interviewees did not answer all the questions, especially those related to personal economic aspects. The overestimation usually increases with the measurement errors, specifically related to the difficulty of the angler in remembering past fishing events and the tendency to magnify their effort and catch over time (the recall bias) (Fisher et al. 1991, Pollock et al. 1994). These errors can also be influenced by factors such as the frequency of participation (Thompson and Hubert 1990) or by inaccurate statements by some anglers with regard to the catch amounts or their expenditure (Pita et al. 2018).

It should also be noted that some of the confidence intervals obtained are very large, indicating that there is great heterogeneity in the surveyed population. These data reflect the great variability of the Madeiran anglers, so the extrapolation of the results obtained to the population level may be imprecise. Nevertheless, despite the limitations and inaccuracies inherent to surveys, they still provide valuable information and give a general perception of the recreational shore fisheries in Madeira. 


\section{CONCLUSIONS}

The present study demonstrates the importance of the recreational shore angling sector in the ultraperipheral region of Madeira, contributing to the understanding of the implications of shore angling and the importance of establishing connections between anglers, researchers and legislators. The results also support the need to incorporate basic data from recreational fisheries in the management of fish stocks.

It would be interesting to design and implement a system for collecting information on this sector, monitoring recreational fisheries in the region in order to quantify the real effort and abundance of the species captured. Evolution of captures and effort over the years should be registered to generate time series for the inclusion of results in stock assessments. It is important to make a greater effort in collecting information more accurately, and to follow up on the catches in each fishery, including sampling fish sizes. In addition, these data could be strengthened by encouraging anglers to voluntarily provide their catch data. A possible solution could include the development of mobile applications that simulate logbooks (Venturelli et al. 2017), or requiring anglers to fill in a questionnaire on the previous fishing season when obtaining their licence. Also, inspectors should collect information on catches and fish sizes when carrying out controls, which should occur on a more regular basis, thus generating a database that can be analysed later by researchers.

Although the results estimated in this study may be subject to some bias, this is the first work describing the recreational fisheries in Madeira. These results are an important contribution to supporting fisheries management in the region, and could be the beginning of a monitoring programme of recreational fisheries. The integration of different sectors of society, including anglers, fishing associations, scientists, inspectors and legislators, is necessary to achieve a suitable management of recreational fisheries (Arlinghaus et al. 2014, 2016), particularly in a small region like Madeira.

\section{DATA AVAILABILITY}

There are no linked research data sets for this submission. Data will be made available on request.

\section{ACKNOWLEDGEMENTS}

Thanks to all the anglers who contributed with their time and their responses to make this study possible. Thanks to Francesca Gizzi for helping in the revision and improving the manuscript and to Fernando Alexandre for the native English language revision. Roi Martínez-Escauriaza was financially supported by the Oceanic Observatory of Madeira Project (M142001-0145-FEDER-000001-Observatório Oceânico da Madeira-OOM). Margarida Hermida was financially supported by a postdoctoral grant from the Regional Agency for Development of Research, Technology and Innovation of Madeira (ARDITI), project M1420-09-5369-FSE-000001.

\section{REFERENCES}

Alves F., Alves C. 2002. Two new records of seabreams (Pisces: Sparidae) from the Madeira Archipelago. Arquipélago, Life Mar. Sci. 19A: 107-111.

Araújo R., Freitas M., Monteiro J. 2008. Eco-parque Marinho do Funchal. Ed. Oceanográfica, 125 pp.

Arechavala-Lopez P., Toledo-Guedes K., Izquierdo-Gomez D., et al. 2018. Implications of sea bream and sea bass escapes for sustainable aquaculture management: a review of interactions, risks and consequences. Rev. Fish. Sci. Aquac. 26: 214-234. https://doi.org/10.1080/23308249.2017.1384789

Arlinghaus R., Cooke S.J. 2009. Recreational Fisheries: Socioeconomic Importance, Conservation Issues and Management Challenges. In: Dickson B., Hutton J. et al. (eds), Recreational Hunting, Conservation and Rural Livelihoods: Science and Practice, Blackwell Publishing. S.L, Oxford, UK, pp. 39-58. https://doi.org/10.1002/9781444303179.ch3

Arlinghaus R., Hunt L.M., Post J.R., et al. 2014. Not fish not meat: some guidance on how to study fisheries from an interdisciplinary perspective. In: Taylor W.W., Lynch A.J., et al. (eds), Future of Fisheries: Perspectives for Emerging Professionals. Am. Fish. Soc., Bethesda, MD, pp. 223-230.

Arlinghaus R., Tillner R., Bork M. 2015. Explaining participation rates in recreational fishing across industrialized countries. Fish. Manag. Ecol. 22: 45-55. https://doi.org/10.1111/fme.12075

Arlinghaus R., Cooke S.J., Sutton S.G., et al. 2016. Recommendations for the future of recreational fisheries to prepare the social-ecological system to cope with change. Fish. Manag. Ecol. 23: 177-186. https://doi.org/10.1111/fme.12191

Attwood C.G., Bennett B.A. 1995. A procedure for setting daily bag limits on the recreational shore-fishery of the South-Western Cape, South Africa. S. Afr. J. Mar. Sci. 15: 241-251. https://doi.org/10.2989/025776195784156377

Balart E.F., Pérez-Urbiola J.C., Campos-Dávila L., et al. 2009. On the first record of a potentially harmful fish, Sparus aurata in the Gulf of California. Biol. Invasions 11: 547-550. https://doi.org/10.1007/s10530-008-9269-3

Brouwer S.L., Mann B.Q., Lamberth S.J., et al. 1997. A survey of the South African shore-angling fishery. S. Afr. J. Mar. Sci. 18: $165-177$. https://doi.org/10.2989/025776197784161126

Cardona F., Morales-Nin B. 2013. Anglers' perceptions of recreational fisheries and fisheries management in Mallorca. Ocean. Coast. Manage. 82: 146-150. https://doi.org/10.1016/j.ocecoaman.2013.06.006

Cisneros-Montemayor A.M., Sumaila U.R. 2010. A global estimate of benefits from ecosystem-based marine recreation: Potential impacts and implications for management. J. Bioecon. 12: 245-268. https://doi.org/10.1007/s10818-010-9092-7

Coleman F.C., Figueira W.F., Ueland J.S., et al. 2004. The impact of United States recreational fisheries on marine fish populations. Science 305: 1958-1960. https://doi.org/10.1126/science. 1100397

Cooke S.J., Cowx I.G. 2004. The role of recreational fishing in global fish crises. Bioscience 54: 857-859. https://doi.org/10.1641/0006-3568(2004)054[0857:TRORFI]2 $0 . \mathrm{CO} ; 2$

Cooke S.J., Cowx I.G. 2006. Contrasting recreational and commercial fishing: searching for common issues to promote unified conservation of fisheries resources and aquatic environments. Biol. Conserv. 128: 93-108. https://doi.org/10.1016/j.biocon.2005.09.019

Cowx I.G. 2008. Recreational Fishing. In: Hart P.J.B., Reynolds J.D. (eds), Handbook of Fish Biology and Fisheries. Blackwell Science Ltd. pp. 367-390. https://doi.org/10.1002/9780470693919.ch17

Diogo H., Pereira J.G. 2014. Assessing the potential biological implications of recreational inshore fisheries on sub-tidal fish communities of Azores (north-east Atlantic Ocean) using catch and effort data. J. Fish. Biol. 84: 952-970. https://doi.org/10.1111/jfb.12336

Direção Regional de Estatística da Madeira. 2018. https://estatistica.madeira.gov.pt

FAO. 2016. The State of World Fisheries and Aquaculture 2016 Contributing to food security and nutrition for all. Rome. 200 pp.

Fisher M.R. 1996. Estimating the effect of nonresponse bias on angler surveys. Trans. Am. Fish. Soc. 125: 118-126. 
https://doi.org/10.1577/1548-8659(1996)125<0118:ETEONB> 2.3. CO;2

Fisher W.L., Grambsch A.E., Eisenhower D.L., et al. 1991. Length of recall period and accuracy of estimates from the National Survey of Fishing, Hunting, and Wildlife-Associated Recreation. Am. Fish. Soc. Symp. 12: 367-374.

Font T., Lloret J. 2011. Socioeconomic implications of recreational shore angling for the management of coastal resources in a Mediterranean marine protected area. Fish. Res. 108: 214-217. https://doi.org/10.1016/j.fishres.2010.11.022

Froese R., Pauly D. (eds). 2019. FishBase. World Wide Web electronic publication, version (12/2019). Online at: http://www.fishbase.org

Gordoa A., Dedeu A.L., Boada J. 2019. Recreational fishing Spain: First national estimates fisher population size fishing activity fisher social profile. Fish. Res. 211: 1-12. https://doi.org/10.1016/j.fishres.2018.10.026

Groves R.M., Fowler F.J., Couper M.P., et al. 2004. Survey Methodology. Wiley J. and Sons. Hoboken, New Jersey.

Hermida M., Costa S. 2020. Between Tradition and Taste: Fish Consumption Habits in a Small Portuguese Archipelago. J. Aquat. Food Prod. Technol. 29: 335-349. https://doi.org/10.1080/10498850.2020.1734892

Hermida M., Delgado J. 2016. High trophic level and low diversity: Would Madeira benefit from fishing down? Mar. Policy 73: 130-137. https://doi.org/10.1016/j.marpol.2016.07.013

Hickley P., Tompkins H. 1998. Recreational fisheries: social, economics and management aspects. Oxford, U.K., 328 pp.

Hyder K., Weltersbach M.S., Armstrong M., et al. 2018. Recreational sea fishing in Europe in a global context - participation rates, fishing effort, expenditure, and implications for monitoring and assessment. Fish. Fish 19: 225-243. https://doi.org/10.1111/faf.12251

Lewin W.C., Arlinhaus R., Mehner T. 2006. Documented and potential impacts of recreational fishing: Insights for Management and Conservation. Rev. Fish. Sci. 14: 305-367. https://doi.org/10.1080/10641260600886455

Lloret J., Cowx I.G., Cabral H., et al. 2016. Small-scale coastal fisheries in European Seas are not what they were: ecological, social and economic changes. Mar. Policy 98: 176-186. https://doi.org/10.1016/j.marpol.2016.11.007

Lockwood R.N. 2000. Conducting roving and access site angler surveys. In: Schneider J.C. (ed.), Manual of Fisheries Survey Methods II. Michigan Department of Natural Resources, Fish. Spec. Rep. 25.

Lopo M.P.E. 2004. Avaliação do Impacto da Extração de Inertes em Espécies Estuarinas de Peixes. MSc thesis, Inst. Ciênc. Bioméd. Abel Salazar. Univ. Porto, $81 \mathrm{pp}$.

McPhee D.P., Leadbitter D., Skilleter G.A. 2002. Swallowing the bait: is recreational fishing ecologically sustainable? Pac. Conserv. Biol. 8: 40-51. https://doi.org/10.1071/PC020040

National Research Council (NRC). 2006. Review of recreational fisheries survey methods. National Academy of Sciences Press, Washington. 187 pp.

Pascual-Fernández J.J., Chinea-Mederos I., Santana-Talavera A., et al. 2012. La pesca recreativa en Tenerife y su regulación. Cabildo Insular de Tenerife. Santa Cruz de Tenerife, 48 pp.

Pauly D., Alder J., Bennett E., et al. 2003. The future for fisheries. Science 302: 1359-1361. https://doi.org/10.1126/science.1088667

Pham C.K., Canha A., Diogo H., et al. 2013. Total marine fisheries catch for the Azores (1950-2010). ICES J. Mar. Sci. 70: 564-577. https://doi.org/10.1093/icesjms/fst024

Pita P.,Alonso A., Arlinghaus R., et al. 2016. Informe técnico del I Taller sobre Pesca Recreativa en el litoral Atlántico Ibérico, In: Pita P., Villasante S. (eds), I Taller sobre Pesca Recreativa en el litoral Atlántico Ibérico. 115 pp.

Pita P., Hyder K., Gomes P., et al. 2017a. Características económicas, sociales y ecológicas de la pesca marítima recreativa en Galicia. In: Pita P., Villasante S. (eds), Informe técnico del Proyecto RECREGES. 56 pp.

Pita P., Artetxe I., Diogo H., et al. 2017b. Research and management priorities for Atlantic marine recreational fisheries in Southern Europe. Mar. Policy 86: 1-8. https://doi.org/10.1016/j.marpol.2017.08.030

Pita P., Hyder K., Gomes P., et al. 2018. Economic, social and ecological attributes of marine recreational fisheries in Galicia,
Spain. Fish. Res. 208: 58-69. https://doi.org/10.1016/j.fishres.2018.07.014

Pollock K.H., Jones C.M., Brown T.L. 1994. Angler survey methods and their aplications in fisheries management. Am. Fish. Soc. Special Publication. 25, Bethesda, Maryland, 371 pp.

Post J.R., Sullivan M., Cox S., et al. 2002. Canada's recreational fisheries: The invisible collapse? Fisheries 27: 6-17.

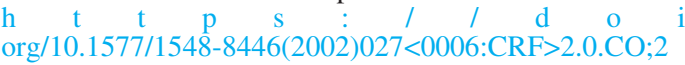

Quintal R. 2004. Levadas e Veredas da Madeira. Ribeiro F. Ed., Funchal, $286 \mathrm{pp}$.

Rangel M.O., Erzini K. 2007. An assessment of catches and harvest of recreational shore angling in the north of Portugal. Fish. Manag. Ecol. 14: 343-352. https://doi.org/10.1111/j.1365-2400.2007.00560.x

Ribeiro M.A., Ramalho M. 2009. Uma visita geológica ao Arquipiélago de Madeira. Principais locais Geo-Turísticos, INETInovação, Laboratório Nacional de Energia e Geologia. 91 pp.

Ruiz J., Zarauz L., Urtizberea A., et al. 2014. Establecimiento de un sistema de recogida sistemática de datos sobre pesca recreativa. Eusko Jaurlaritza, Gobierno Vasco.

https://www.euskadi.eus/contenidos/informacion/proyectos fep/es_def/adjuntos/Recrea\%202012.pdf

Smallwood C.B., Pollock K.H., Wise B.S., et al. 2011. Quantifying recreational fishing catch and effort: a pilot study of shorebased fishers in the Perth Metropolitan area. CB Fish. Res. Report, $60 \mathrm{pp}$

Toledo-Guedes K., Sanchez-Jerez P., Brito A. 2014. Influence of a massive aquaculture escape event on artisanal fisheries. Fish. Manage. Ecol. 21: 113-121. https://doi.org/10.1111/fme.12059

Thompson T., Hubert W.A. 1990. Influence of survey method on estimates of statewide fishing activity. North Am. J. Fish. Manage. 10: 111-113. https://doi.org/10.1577/1548-8675(1990)010<0111:IOSMOE> 2.3. $\mathrm{CO} ; 2$

Veiga P. 2012. Recreational shore fishing in southern Portugal: biological and socio-economic aspects and perspectives for management. MSc thesis, Univ. Algarve, $175 \mathrm{pp}$

Veiga P., Ribeiro J., Gonçalves J.M.S., et al. 2010. Quantifying recreational shore angling catch and harvest in southern Portugal (north-east Atlantic Ocean): implications for conservation and integrated fisheries management. J. Fish. Biol. 76: 2216-2237. https://doi.org/10.1111/j.1095-8649.2010.02665.x

Veiga P., Pita C., Leite L., et al. 2013. From a traditionally open access fishery to modern restrictions: Portuguese anglers' perceptions about newly implemented recreational fishing regulations. Mar. Policy 40: 53-63. https://doi.org/10.1016/j.marpol.2012.12.037

Venturelli P.A., Hyder K., Skov C. 2017. Angler apps as a source of recreational fisheries data: Opportunities, challenges and proposed standards. Fish Fish. 18: 578-595. https://doi.org/10.1111/faf.12189

Villasante S. 2009. Magnitud e implicaciones de la Política Pesquera Comunitaria: aplicación de indicadores de sostenibilidad sobre el metabolismo de los ecosistemas marinos. Ph.D. thesis, Univ. Santiago de Compostela, 613 pp.

Watson R., Tyedmers P., Kitchingman A., et al. 2003. What's left: The emerging shape of the global fisheries crisis. Conserv. Pract. 4: 20-21.

Wirtz P., Fricke R., Biscoito M.J. 2008. The coastal fishes of Madeira Island-new records and an annotated check-list. Zootaxa 1715: 1-26. https://doi.org/10.11646/zootaxa.1715.1.1

Zarauz L., Ruiz J., Urtizberea A., et al. 2015. Comparing different survey methods to estimate European sea bass recreational catches in the Basque Country. ICES J. Mar. Sci. 72: 1181-1191. https://doi.org/10.1093/icesjms/fsv054

Zeller D., Darcy M., Booth S., et al. 2008. What about recreational catch?: Potential impact on stock assessment for Hawaii's bottomfish fisheries. Fish. Res. 91: 88-97. https://doi.org/10.1016/j.fishres.2007.11.010

\section{SUPPLEMENTARY MATERIAL}

The following supplementary material is available through the online version of this article and at the following link:

http://scimar.icm.csic.es/scimar/supplm/sm05046esm.pdf

Questionnaire used in the survey. 


\section{Importance of recreational shore angling in the archipelago of Madeira, Portugal (northeast Atlantic)}

Roi Martínez-Escauriaza, Margarida Hermida, Sebastián Villasante, Lídia Gouveia, Nuno Gouveia, Pablo Pita

Supplementary material 
Questionnaire used in the survey.

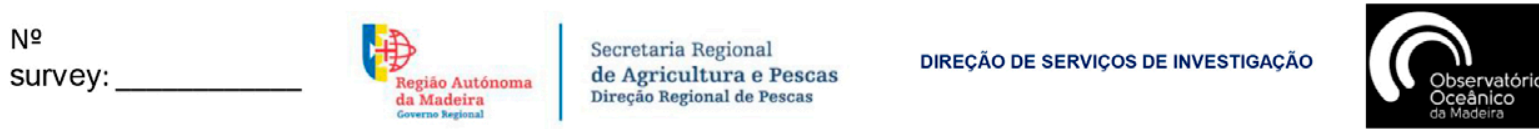

\section{Personal data}

Place of interview:

Date: Time:

Age: years

Gender: Male $\square$ Female $\square$

Nationality:

Naturalness:

County where you live :

Profession: Unemployed $\square$ Student $\square$ Self-employed $\square$ Employed worker $\square$ Public server $\square$ Retired $\square$

Marital status: Single $\square \quad$ Married $\square \quad$ Widower $\square \quad$ Divorced $\square$

Education: No studies $\square$ Basic Studies $\square$ Technical Education $\square$ Graduation $\square$

Monthly salary: No income $\square \quad 0-500 € \square \quad 500-1000 € \square \quad 1000-1500 € \square \quad>1500 € \square$

\section{Fishery data}

Modality of license : Annual $\square$ Monthly $\square$

Alone $\square$ Accompanied $\square$

Years of experience:

Member of a fishing association?: Yes $\square$ No $\square$

Expenditure on fishing equipment (year): $€$

Usual schedule : Morning $\square$ Afternoon $\square$ Noite $\square$ Depends on the tide $\square$ Indifferent $\square$ Time (Hours):

Frequency: Almost every day $\square$ 2-3 times per week $\square \quad 1$ time per week $\square \quad 1$ time per month $\square$ Other:

Favorite Days: During the week $\square$ Weekend or holidays $\square$ Indifferent $\square$

Seasonal distribution: All the year $\square$ Jan $\square$ Fev $\square$ March $\square$ April $\square$ May $\square$ Jun $\square$ Jul $\square$ Aug $\square$ Sept $\square$ Oct $\square$ Nov $\square$ Dec $\square$

Favorite places to fish :

Areas where the activity is carried out :

Beach $\square$

Rocks $\square$

Promenade, harbor, pier $\square$

Fishing Art:

Bottom fishing $\square$ Fishing with float $\square$ Spinning $\square$ Hand line $\square$ Other:

Bait: Artificial $\square$ Natural $\square$ Bought $\square$ Captured $\square$ Bread $\square$ List:

Average amount by exit $(\mathrm{Kg})$ :

Destination of caught fish: Own consumption $\square \quad$ Donation $\square \quad$ Release $\square \quad$ Sale $\square$ 


\section{List of species most frequently caught}

\begin{tabular}{|c|c|}
\hline Common name of the species & Common name of the species \\
\hline Almaco jack & Limpet \\
\hline Atlantic wrasse & Lizardfish \\
\hline Axillary seabream & Madeira rockfish \\
\hline Azores chromis & Madeiran sardinella \\
\hline Bastard grunt & Mediterranean rainbow wrasse \\
\hline Bermuda sea chub & Moray \\
\hline Blackspot seabream & Mullet \\
\hline Blacktail comber & Ornate wrasse \\
\hline Blue jack mackerel & Parrotfish \\
\hline Bluefish & Pink dentex \\
\hline Bogue & Pompano \\
\hline Canary damsel & Ray \\
\hline Chub mackerel & Red porgy \\
\hline Common octopus & Saddled seabream \\
\hline Common pandora & Salema \\
\hline Common squid & Sand steenbras \\
\hline Common two-banded seabream & Sea snail \\
\hline Conger eel & Smooth-hound \\
\hline Crabs & Striped red mullet \\
\hline Cuttlefish & White seabream \\
\hline European pilchard & White trevally \\
\hline Crabs & Wide-eyed flounder \\
\hline Forkbeard & Yellowmouth barracuda \\
\hline Garfish & Zebra seabream \\
\hline Gilthead seabream & Other \\
\hline Grey triggerfish & \\
\hline
\end{tabular}

What is your opinion about the amount of catches with respect to previous years:

Increased $\square \quad$ Same $\square$ Decreased $\square$

Possible causes:

Pollution $\square$ Overfishing $\square$ Commercial fishing $\square$ Construction works $\square$ Inadequate regulations $\square$ Climate change $\square$ Other:

Considers that the average number of species whichhabitually catches:

Increased $\square \quad$ Same $\square \quad$ Decreased $\square$

Do you think that the number of people practicing shore angling :

Increased $\square \quad$ Same $\square \quad$ Decreased $\square$

Do you participate in any form of the sport fishing competitions that take place in R.A.M?

Yes $\square$

No $\square$

Knows the regulation related to recreational fishing for R.A.M .:

Yes $\square \quad$ No $\square \quad$ More or less $\square$

What would change in the current legislation?

Opinion: 